\title{
Analysis and Suggestion about Offering Course of Water Law in Vocational College of Water Conservancy
}

\author{
Sihui Hao \\ Henan Vocational College of Water Conservancy and Environment, Zhengzhou, Henan Province, 450008
}

Keywords: Vocational College of water conservancy, Water law course, Analysis, Suggestion.

\begin{abstract}
Since Water Law of PRC was promulgated, our country's water conservancy business has entered a new period of managing water according to law, and water conservancy career has taken to the track of legal system construction. When students from vocational college of water conservancy graduate, most of them will go in for the work which is related to water conservancy. If vocational college of water conservancy offer course of Water Law, it is helpful for students to work and for country to speed up the legalization process of water conservancy construction.
\end{abstract}

\section{Background of Water Law}

Water Law of PRC was approved by the Standing Committee of the Sixth National People's Congress on January 21, 1988 and implemented on July 1, 1988. With the rapid development of economy and society and the fundamental change of water conservancy situation, the revision of Water Law is objective and practical necessity, and it is also the necessity of historical development. Therefore, on August 29, 2002, Water Law of PRC was revised and passed by the $29^{\text {th }}$ meeting of the Standing Committee of the Ninth National People's Congress, and the revised Water Law of PRC should be formally implemented from October 1, 2002.

Since this law has been implemented, cadres and people have better understanding about water conservancy. They have certain depth about broadcasting, learning and understanding of the Water Law. Construction of legal system on water conservancy, which is in the three centers of legislation, administration and law enforcement system, has also made many notable achievements. Water conservancy work gradually took to the orbit of legal system. But we also should see that although Water Law has been implemented for 30 years, there are still some water relations and problems which have not been smooth. In order to achieve managing water conservancy according to, there are quite a few difficulties. Task is quite formidable, and country still has a lot of work to do.

\section{Analysis and Suggestion about Offering Course of Water Law in Vocational College of Water Conservancy}

At present, with the growth of the population and the rapid development of economic society, water resource problems, especially the contradictions between the shortage of water resources and the development of economy and society, have been fully exposed. Water resources become rare. Therefore, it is very important to do good work in using water and managing water. Vocational education of water conservancy is aimed at cultivating technological talents for the need of water production, construction, management and service. Vocational college of water conservancy provide important support and guarantee for healthy development of each work in water conservancy business. The majority of graduates will be engaged in the work related to water conservancy, such as water conservancy, water and electricity engineering design, construction, supervision, management, maintenance and other jobs. Due to the implementation of Water Law need gradual and deep development, combined with the particularity of water conservancy work, it is necessary for vocational college of water conservancy to offer Water Law course. Vocational college of water conservancy should reform the curriculum and put Water Law on teaching content. By offering 
Water Law and related courses, students can completely and systematically study Water Law and related courses, it will be beneficial for students and for the country's water conservancy construction.

Firstly, offering Water Law curriculum is the need of adapting to social development and situation.

Our country has gradually built up the various laws and regulations, promoted the building of democracy and legal system, carried out the administration rules by law step by step. In the speech of celebrating the $60^{\text {th }}$ anniversary of the founding of the National People's Congress conference, President Xi pointed out that we must adhere to the rule of law as a basic strategy for the party to lead the people in the governance of the country, regard the rule of law as the basic way of governing, and continuously push forward the Chinese rule of law construction. The formulation and implementation of Water Law and related laws about adjusting water relations is good beginning of controlling water according to law, is the legal basis of building water resources industry, and is the protection of promoting the reform of water resources industry to develop rationally. It can further improve the water system in our country and is the basis of strengthening the management of water resources projects work. Water conservancy work involves the vital interests of families in all walks of life and work. It is good for the benefit of society and the vast majority of people. At the same time, it is difficult to avoid damage of interests of local regions and minority work. Also it is hard to avoid errors and defects in work, which will damage the legitimate rights and interests of some people. After the implementation of Administrative Procedure Law, especially in the future, there will be more and more water disputes changing into suits in people's court. Water resource case will be increasing, so the department of water conservancy should have this kind of concept and fully prepare.

Therefore, in the future, in the work of water conservancy, water resource units and staff must work in accordance with Water Law, relevant laws and regulations. It is hard for a water resource worker, who doesn't understand water laws and regulations, to handle all kinds of water issues properly. The most fundamental way to solve this problem is to rely on education. School education must adapt to the need of new situation in which society should implement rule of law step by step. Also school education should cultivate talents for the socialist modernization who both have professional technical knowledge of water conservancy and know the law and use the law. In order to achieve this goal, vocational college of water conservancy can reform the existing curriculum of the school according to the actual situation of the local region, and generally add relevant courses such as Water Law as the required public course.

Secondly, offering Water Law curriculum is the need of completing the education target.

Education is for modernization and for the future. The total goal of training talents in Chinese education is to cultivate the ideal, moral, cultured and disciplined workers of virtue, intelligence and body. To be disciplined, we must first understand the laws and regulations. Although at present our country's construction of legal system is not very perfect, it also has enacted dozens of laws, hundreds of laws and regulations. Even if school lets students have a general understanding about some basic laws, they need a certain amount of time to study. Therefore, in the process of study, school should think about characteristics of teenagers with different ages, the actual thought, receiving ability and their ideological and moral development rule. Of course, school should follow the principle of going from the easy to the difficult. In the schools of various levels, they can carry out the common legal system education, forming systematic and legal education system, which is from primary school to university, from parent law to ordinary law. In this regard, the deployment of education in the municipal legal system of Shanghai is worth learning and borrowing. Primary school stage mainly carries on enlightenment education about the socialist democracy and the legal concept. Junior high school stage mainly carries on socialist democracy education. In senior high school, the basic law of socialist democracy and the legal system is mainly used. In vocational and technical school, except the content in senior high school, professional regulations and work regulations education are carried on according to their professional characteristics.

At present, primary and secondary schools have not yet pervasive in this education mode. In 
addition to normal law-related programs, education of legal system in vocational college of water conservancy should also set up Water Law course associated with the water conservancy industry. Colleges can guide students to dabble in some ideas of water legal system appropriately. They can also educate students by using some basic knowledge of Water Law and legal system construction. This reform is arguably one of the urgent tasks of current vocational education reform of water conservancy. It is an urgent and required task which is to finish the task of vocational education of water conservancy and to realize the teaching goal of vocational education of water conservancy.

Thirdly, offering Water Law curriculum is the need of better completing the technical business.

In a country that executes the rule of law, law is the basis for handling affairs and work. Water Law and other laws related to water matters and water conservancy regulations are the basic basis for various water activities and various water conservancy planning, design, construction and management. Under the new situation, a water conservancy worker not only knows the law himself. At the same time, the decision, planning, design and related policies he makes must conform to the technical specification. They should fully achieve legal aim. Otherwise, it will bring loss to work, and they are even caught in the path of crime.

Water relations are complex. There are interests between the parties and interests between the national macro-control and the parties, namely, the vertical relationship and the horizontal relations are often crossed. For example, to plan, design, construct a hydropower station or a reservoir, related staff must be familiar with the relevant provisions in the water act rules and principles. For example, in the fourth rule of Water Law, Development, utilization, conservation and protection of water resources and the prevention and control of water disasters, should be comprehensive planning, overall consideration, symptoms, comprehensive utilization, stressing efficiency, playing a variety of functions of water resources, coordinating the use of water among life, production and operation, and the ecological environment. In the twentieth rule of Water Law, The development and utilization of water resources shall adhere to the combination of promoting what is beneficial and abolishing what is harmful, give consideration to the interests of both upstream and downstream, two shores and related regions. In the twenty-sixth rule of Water Law, Country encourages development and utilization of water resources. In water-rich rivers, multi-objective cascade development should be carried out in a planned way. The construction of hydroelectric power stations should protect the ecological environment and give consideration to the needs of flood control, water supply, irrigation, shipping, bamboo and wood exile and fishery. In the twenty-seventh rule of Water Law, Country encourages the development and utilization of water transport resources. When building permanent sluice and dam on the rivers which belongs to migration routes, navigation rivers or bamboo and log rafting rivers, the construction unit shall simultaneously build facilities for fish, boat, and wood. Or they can take other remedial measures after being approved by departments authorized by State Council, and properly arrange protection of aquatic organisms, shipping and bamboo and log rafting during construction and water storage. The construction unit offers costs. If related provisions of Water Law are violated, it will bring loss and bad consequences to country and people. In the past, in the construction of water conservancy projects and hydroelectric power projects, there were places existing problems, such as obstruction of fishing or shipping. Although some remedial measures were adopted, there were still some problems that were not solved. In the aspects of ecological environment protection, management of water project and protection of water resource, there are also many problems which should be solved. We should never forget the lesson. Students study the knowledge of water laws and regulations combining knowledge of water conservancy and let the expertise knowledge and legal knowledge melt into each other. When they graduate from school, legal knowledge will play the role of restriction and protection in the correct application of professional and technical knowledge.

\section{Conclusion}

In a word, vocational college of water conservancy offer Water Law and related courses, and it is the need of technical work of water conservancy under the new situation. Also it is the need of 
developing strong adaptability, high strain capacity, and technology, comprehensive water conservancy of professional and technical personnel. They are helpful for students to engage in related work and beneficial for the legalization process of national construction of water conservancy. Vocational college of water conservancy should fully realize the importance of offering Water Law and other related courses and put them into practice.

\section{References}

[1] Zhili Chen. Further promoting the implementation of Water Law of PRC -- speech on the revised 10th anniversary of Water Law of PRC [J]. Water Resources Development Research, 2012, (10)

[2] Jiatao Zhang. Water law construction and water conservancy modernization[J]. Water Resources Development Research, 2013, (3) 